\title{
OPTIMASI AGROINDUSTRI LIDAH BUAYA
}

\section{OPTIMIZED VOCATIONAL AGROINDUSTRY}

\author{
Betty Rofatin'a, Enok Sumarsih ${ }^{1}$ \\ 1Universitas Siliwangi, Jl Siliwangi No. 24 Tasik Malaya. \\ a Korespondensi:Butty Rofatin, E-mail: bettyrofatin@unsil.ac.id \\ (Diterima: 06-12-2019; Ditelaah: 07-12-2019; Disetujui: 28-09-2020)
}

\begin{abstract}
Aloe vera processing into various kinds of food or beverage products will be faced with capital use activities. To produce maximum output, the company will certainly be faced with the raw materials it has and other supporting materials, but to produce maximum output, the amount needed will exceed that provided. This condition requires companies to make the right combination so that the needs do not exceed the amount provided. Likewise with labor which is an important part in the production process. This study aims to determine the actual condition of aloe vera based agroindustry, optimal conditions of aloe vera based agroindustry, and the difference in revenue before and after optimization on aloe vera agroindustry on LIBUA Agroindustry in Indihiang District, Tasikmalaya City. This research uses a case study method in LIBUA Agroindustry in the District of Indihiang, Tasikmalaya City. The analysis used is Linear Programming analysis. The results of research on the actual condition of agroindustry made from aloe vera, showed production results for nata de aloe 33.5 kilograms and 7 kilograms jam, with a price of nata de aloe Rp 100,000, - / kg and jam Rp 75,000, - / kg, so as to obtain revenue for nata de aloe de aloe Rp. 3,350,000 and jam Rp. 525,000, - with a total revenue of Rp. $3,875,000$. Based on the optimal conditions the production results obtained for nata de aloe 40.72 kilograms and do not produce jam at a price of Rp. 100,000.0 / kg, so that an income of Rp. 4,072,000. Thus there is a difference in revenue after optimization which is Rp. 197,000
\end{abstract}

Keyword : Aloe vera, capital, labor, optimization.

\begin{abstract}
ABSTRAK
Pengolahan lidah buaya menjadi berbagai macam produk makanan atau minuman akan dihadapkan pada aktifitas penggunaan modal. Untuk menghasilkan output yang maksimal, perusahaan pasti akan dihadapkan pada bahan baku yang dimilikinya serta bahan-bahan pendukung lainnya, tetapi untuk menghasilkan output yang maksimal, jumlah yang dibutuhkan akan melebihi yang disediakan. Kondisi ini mengharuskan perusahaan untuk melakukan kombinasi yang tepat agar kebutuhan tidak melebihi dari jumlah yang disediakan. Begitu juga dengan tenaga kerja yang merupakan bagian penting dalam proses produksi. Penelitian ini bertujuan untuk mengetahui kondisi aktual agroindustri berbahan baku lidah buaya, kondisi optimal agroindustri berbahan baku lidah buaya , dan selisih penerimaan sebelum dan setelah dilakukan optimasi pada Agroindustri lidah buaya pada Agroindustri LIBUA di Kecamatan Indihiang Kota Tasikmalaya. Penelitian ini menggunakan metode studi kasus pada Agroindustri LIBUA di Kecamatan Indihiang Kota Tasikmalaya. Analisis yang digunakan adalah analisis Linear Programming. Hasil penelitian tentang kondisi aktual agroindustri berbahan baku lidah buaya, menunjukkan hasil produksi untuk nata de aloe 33.5 kilogram dan selai 7 kilogram, dengan harga nata de aloe $\mathrm{Rp} 100.000,-/ \mathrm{kg}$ dan selai $\mathrm{Rp} 75.000,-/ \mathrm{kg}$, sehingga diperoleh penerimaan untuk nata de aloe sebesar Rp. 3.350.000,- dan selai Rp. 525.000,- dengan total penerimaan sebesar Rp. 3.875.000,-

Berdasarkan kondisi optimal diperoleh hasil produksi untuk nata de aloe 40,72 kilogram dan tidak memproduksi selai dengan harga Rp. 100.000,0/kg, sehingga diperoleh penerimaan sebesar Rp. 4.072.000,-. Dengan demikian ada perbedaad penerimaan setelah optimasi yaitu sebesar Rp. 197.000,-

Kata Kunci : Optimasi, lidah buaya, modal, tenaga kerja.
\end{abstract}


Rofatin. B., \& Sumarsih. E. (2020).Optimasi Agroindustri lidah Buaya. Jurnal Pertanian, 11(2); 56-63.

\section{PENDAHULUAN}

Pengembangan agribisnis lidah buaya di Indonesia terpusat di Pontianak Propinsi Kalimantan Barat. Lidah buaya juga banyak diusahakan di Pulau Jawa, tetapi skala usahanya relatif sempit dan lokasinya terpencar. Pengembangan lidah buaya di Jawa Barat berada di daerah Bogor dan Parung.

Lidah buaya dapat diolah menjadi berbagai produk olahan seperti dodol, selai, sirup dan lainlain. Agroindustri Lidah Buaya "Libua" merupakan salah satu agroindustri yang memproduksi berbagai variasi produk olahan lidah buaya di Tasikmalaya. Ada beberapa jenis produk olahan lidah buaya yang diproduksi oleh agroindustri tersebut antara lain minuman lidah buaya (nata de aloe), selai lidah buaya, dodol lidah buaya dan teh lidah buaya, namun yang kontinu diproduksi adalah minuman lidah buaya (nata de aloe) dan selai lidah buaya. Selain itu rasa yang khas dan enak menjadikannya tetap diminati sehingga permintaan terhadap produk tersebut kian meningkat. Tentu saja kondisi ini memberikan peluang pengembangan bisnis olahan lidah buaya.

Modal yang dikorbankan harus mampu menghasilkan kepentingan perusahaan baik itu kepentingan produksi maupun orientasi pada penerimaan maksimal. Bagi perusahaan yang memiliki modal tidak terbatas tentunya peluang untuk meningkatkan hasil produksi akan besar salah satunya adalah dengan menambah skala usaha, tetapi perusahaan yang memiliki modal terbatas, tentunya perusahaan harus mampu mencari kombinasi yang tepat dalam penggunaan faktor-faktor produksi. Melalui optimasi, perusahaan akan mampu mengkombinasikan faktor-faktor produksi agar penerimaan maksimal tetap diperoleh.

Penelitian ini bertujuan untuk mengetahui: Kondisi aktual agroindustri berbahan baku lidah buaya, kondisi optimal agroindustri berbahan baku lidah buaya serta mengetahui selisih penerimaan sebelum dan setelah dilakukan optimasi.

\section{MATERI DAN METODE}

Metode penelitian yang digunakan adalah studi kasus pada Agroindustri LIBUA yang terletak di Kelurahan Sirnagalih Kecamatan Indihiang Kota Tasikmalaya. Lokasi dipilih secara sengaja (purposive), dengan pertimbangan bahwa agroindustri tersebut merupakan agroindustri satu-satunya di Kota Tasikmalaya yang memproduksi olahan lidah buaya dengan berbagai macam produk.

Berdasarkan jenis dan teknik pengumpulan data yang diambil dalam penelitian ini terdiri dari : Data primer adalah data yang dikumpulkan dari sumber data pertama dan data sekunder adalah data yang dikumpulkan dari sumber kedua (Soekartawi, 1995). Variabel-variabel yang diamati dalam penelitian ini dapat dilihat pada Tabel 1 berikut:

Tabel 1. Variabel Linier Programming Agroindustri Lidah Buaya.

\begin{tabular}{|c|c|c|c|}
\hline $\begin{array}{c}\text { Macam } \\
\text { Variabel }\end{array}$ & Definisi Variabel & Indikator & Satuan \\
\hline \multirow[t]{2}{*}{$\begin{array}{l}\text { Variabel } \\
\text { Aktifitas }\end{array}$} & \multirow{2}{*}{$\begin{array}{l}\text { Aktifitas yang dipertimbangkan dalam perencanaan } \\
\text { atau program linier adalah aktifitas produksi. } \\
\text { Aktifitas produksi dalam penelitian ini adalah } \\
\text { membuat produk olahan yang berasal dari bahan } \\
\text { baku lidah buaya }\end{array}$} & $\begin{array}{l}\text { a. Produksi Minuman lidah } \\
\text { buaya (nata de aloe) }\left(\mathrm{X}_{1}\right)\end{array}$ & $\mathrm{kg}$ \\
\hline & & \begin{tabular}{|lll} 
b. & Produksi Selai lidah \\
buaya $\left(\mathrm{X}_{2}\right)$ & & \\
\end{tabular} & $\mathrm{kg}$ \\
\hline \multirow{7}{*}{$\begin{array}{l}\text { Variabel } \\
\text { batasan } \\
\text { atau fungsi } \\
\text { kendala }\end{array}$} & \multirow{7}{*}{$\begin{array}{l}\text { Bentuk penyajian secara sistematis batasan-batasan } \\
\text { kapasitas yang tersedia yang akan dialokasikan } \\
\text { secara optimal keberbagai kegiatan }\end{array}$} & a. Bahan Baku $\left(\mathrm{a}_{1 \mathrm{n}}\right)$ & $\mathrm{kg}$ \\
\hline & & b. Gula $\left(a_{2 n}\right)$ & $\mathrm{kg}$ \\
\hline & & c. $\quad$ Sirup $\left(a_{3 n}\right)$ & botol \\
\hline & & d. Agar-agar (a $4 \mathrm{n})$ & bugkus \\
\hline & & e. Air mineral $\left(a_{5 n}\right)$ & liter \\
\hline & & f. $\quad$ Kemasan (a6n) & Cup \\
\hline & & g. $\quad$ Tenaga Kerja $(a 7 n)$ & JKO \\
\hline $\begin{array}{l}\text { Variabel } \\
\text { fungsi } \\
\text { tujuan }\end{array}$ & $\begin{array}{l}\text { Fungsi yang menggambarkan tujuan atau sasaran di } \\
\text { dalam permasalahan LP yang berkaitan dengan } \\
\text { pengaturan secara optimal faktor-faktor produksi, } \\
\text { untuk memperoleh penerimaan maksimal }\end{array}$ & Total penerimaan & $\mathrm{Rp}$ \\
\hline
\end{tabular}


Data yang diamati dalam penelitian ini diantaranya adalah: Bahan baku lidah buaya, dihitung dalam satuan kilogram; Gula, dihitung dalam satuan kilogram; Sirup, dihitung dalam satuan botol $(1$ botol $=450 \mathrm{ml})$; Agar-agar, dihitung dalam satuan bungkus; Air mineral, dihitung dalam satuan liter; Kemasan, dihitung dalam satuan cup; Tenaga kerja, dihitung dalam satuan jam kerja orang (JKO); Tingkat harga masing-masing output, dinilai dalam satuan rupiah per kilogram; Jumlah masing-masing output secara aktual, dihitung dan dinilai dalam satuan kilogram.

Asumsi-asumsi yang berlaku diantaranya : Harga yang digunakan untuk menentukan penerimaan maksimal adalah harga yang berlaku saat penelitian; Naik turunnya nilai $\mathrm{Z}$ dan penggunaan sumber atau fasilitas yang tersedia akan berubah secara sebanding (proporsional) dengan perubahan tingkat kegiatan; Nilai tujuan tiap kegiatan tidak saling mempengaruhi, atau dalam LP dianggap bahwa kenaikan dari nilai tujuan (Z) yang diakibatkan oleh kenaikan suatu kegiatan dapat ditambahkan tanpa mempengaruhi bagian nilai Z yang diperoleh dari kegiatan lain; Keluaran (output) yang dihasilkan oleh setiap kegiatan dapat berupa bilangan bulat atau desimal. Demikian pula nilai $\mathrm{Z}$ yang dihasilkan; Semua parameter yang terdapat dalam model LP $\left(a_{i j}, b_{i}, C_{j}\right)$ dapat diperkirakan dengan pasti, meskipun jarang dengan tepat.

\section{Kerangka Analisis}

Linear programming adalah salah satu teknis analisis dari kelompok teknik riset operasional yang menggunakan model matematik. Tujuannya adalah untuk mencari, memilih dan menentukan alternatif yang terbaik dari sekian alternatif grafis dan metode analisis secara aljabar (metode simpleks). Dengan demikian dapat diartikan sebagai salah satu teknik dari Riset Operasi untuk memecahkan persoalan optimasi (maksimasi atau minimasi) dengan menggunakan persamaan dan ketidaksamaan linier dalam rangka untuk mencari pemecahan yang optimum dengan memperhatikan pembatasan-pembatasan yang ada.

Tujuan dari pada optimasi tidak harus dalam konsep pendapatan atau keuntungan maksimal. Soekartawi (1992), menyatakan bahwa setiap penyelesaian cara Linear Programming untuk maksud mendesain perencanan yang baik agar memaksimumkan tujuan dapat diperoleh salah satunya dengan program memaksimumkan total penerimaan. J. Supranto (1983) menambahkan untuk menentukan fungsi tujuan, harus ditentukan nilai variabel $\mathrm{x}$ melalui persamaan fungsi kendala. Kendala yang berpengaruh terhadap fungsi tujuan dibedakan menjadi dua yaitu ketersediaan bahan baku dan jumlah tenaga kerja. Kendala bahan baku yaitu banyaknya bahan baku $\left(\mathrm{a}_{1 \mathrm{n}}\right)$ yang dibutuhkan untuk pembuatan minuman lidah buaya (nata de aloe) dan selai lidah buaya. Menurut Pangestu Subagyo, dkk (2000),

Formulasinya ditulis sebagai berikut :

$\left(\mathrm{a}_{11} \mathrm{X}_{1}\right)+\left(\mathrm{a}_{12} \mathrm{X}_{2}\right) \leq \mathrm{b}_{1}$

Kendala gula, yaitu banyaknya gula $\left(\mathrm{a}_{2 \mathrm{n}}\right)$ yang dibutuhkan untuk pembuatan minuman lidah buaya (nata de aloe) dan selai lidah buaya.

Rumus matematiknya adalah :

$\left(\mathrm{a}_{21} \mathrm{X}_{1}\right)+\left(\mathrm{a}_{22} \mathrm{X}_{2}\right) \leq \mathrm{b}_{2}$

Kendala sirup, yaitu banyaknya sirup $\left(\mathrm{a}_{3 \mathrm{n}}\right)$ yang dibutuhkan untuk pembuatan minuman lidah buaya (nata de aloe) dan selai liah buaya.

Rumus matematiknya adalah :

$\left(\mathrm{a}_{31} \mathrm{X}_{1}\right)+\left(\mathrm{a}_{32} \mathrm{X}_{2}\right) \leq \mathrm{b}_{3}$

Kendala agar-agar, yaitu banyaknya agar-agar $\left(\mathrm{a}_{4 \mathrm{n}}\right)$ yang dibutuhkan untuk pembuatan minuman lidah buaya (nata de aloe) dan selai liah buaya.

Rumus matematiknya adalah:

$\left(\mathrm{a}_{41} \mathrm{X}_{1}\right)+\left(\mathrm{a}_{42} \mathrm{X}_{2}\right) \leq \mathrm{b}_{4}$

Kendala air mineral, yaitu banyaknya air mineral $\left(\mathrm{a}_{5 \mathrm{n}}\right)$ yang dibutuhkan untuk pembuatan minuman lidah buaya (nata de aloe) dan selai liah buaya.

Rumus matematiknya adalah :

$\left(\mathrm{a}_{51} \mathrm{X}_{1}\right)+\left(\mathrm{a}_{52} \mathrm{X}_{2}\right) \leq \mathrm{b}_{5}$

Kendala kemasan, yaitu banyaknya kemasan $\left(\mathrm{a}_{6 \mathrm{n}}\right)$ yang dibutuhkan untuk pembuatan minuman lidah buaya (nata de aloe) dan selai liah buaya.

Rums matematiknya adalah :

$\left(\mathrm{a}_{61} \mathrm{X}_{1}\right)+\left(\mathrm{a}_{62} \mathrm{X}_{2}\right) \leq \mathrm{b}_{6}$

Kendala tenaga kerja, yaitu banyaknya tenaga kerja $\left(a_{7 n}\right)$ yang dibutuhkan untuk pengolahan minuman lidah buaya (nata de aloe) dan selai liah buaya.

Rums matematiknya adalah :

$\left(\mathrm{a}_{71} \mathrm{X}_{1}\right)+\left(\mathrm{a}_{72} \mathrm{X}_{2}\right) \leq \mathrm{b}_{7}$

Setelah datanya dikumpulkan, selanjutnya data dianalisis dengan paket program QM for window. Sri Mulyono (2007) menyatakan, tujuan dari kombinasi produk adalah untuk memaksimumkan total penerimaan. Total penerimaan adalah jumlah penerimaan yang diperoleh dari masing-masing produk. Penerimaan dari produk satu adalah perkalian antara jumlah produk dengan harga per unit dan penerimaan dua dengan cara serupa. Maka dapat dicari nilai dari total penerimaan pada fungsi 
tujuan yang dapat diformulasikan sebagai berikut.

\section{$\mathrm{Z}=\mathrm{P}_{1} \mathrm{X}_{1}+\mathrm{P}_{2} \mathrm{X}_{2}$}

Keterangan: $\mathrm{Z}$

$=$ Total Penerimaan; $\mathrm{P}_{1}=$ Harga jual nata de aloe; $X_{1}=$ Jumlah hasil produksi nata de aloe; $\mathrm{P}_{2} \quad=$ Harga jual selai lidah buaya; $\mathrm{X}_{2}=$ Jumlah hasil produksi selai lidah buaya. Persamaan diatas, menghasilkan bentuk matrik dasar Linear Programming. Dapat dilihat pada Tabel 2.

Tabel 2. Matrik Dasar Linier Programming.

\begin{tabular}{|c|c|c|c|c|}
\hline Aktifitas atau Kegiatan & \multicolumn{4}{|c|}{$\begin{array}{c}\text { RHS Faktor Produksi yang } \\
\text { Tersedia }\end{array}$} \\
\hline Tingkat Kegiatan & $\mathrm{X}_{1}$ & $\mathrm{X}_{2}$ & $\mathrm{~N}$ & $\begin{array}{l}\text { Rata- } \\
\text { rata }\end{array}$ \\
\hline Fungsi Tujuan (Z) & $\mathrm{C}_{1}$ & $\mathrm{C}_{2}$ & $\rightarrow$ & $Z_{\text {maks }}$ \\
\hline \multicolumn{5}{|l|}{$\begin{array}{l}\text { Fungsi Batasan/Kendala } \\
\text { : }\end{array}$} \\
\hline 1 & $a_{11}$ & $a_{12}$ & $\leq$ & $\mathrm{b}_{1}$ \\
\hline 2 & $a_{21}$ & $a_{22}$ & $\leq$ & $\mathrm{b}_{2}$ \\
\hline 3 & $\mathrm{a}_{31}$ & $a_{32}$ & $\leq$ & $\mathrm{b}_{3}$ \\
\hline 4 & $a_{41}$ & $a_{42}$ & $\leq$ & $\mathrm{b}_{4}$ \\
\hline 5 & $\mathrm{a}_{51}$ & $a_{52}$ & $\leq$ & $\mathrm{b}_{5}$ \\
\hline 6 & $a_{61}$ & $a_{62}$ & $\leq$ & $\mathrm{b}_{6}$ \\
\hline 7 & $\mathrm{a}_{71}$ & $a_{72}$ & $\leq$ & $\mathrm{b}_{7}$ \\
\hline
\end{tabular}

Model LP tersebut merupakan bentuk dan sususnan yang mempunyai masalah-masalah yang akan dipecahkan dengan teknik LP.

Keterangan :

$\mathrm{Z}_{\text {maks }}=$ Nilai yang dioptimalkan yaitu nilai maksimasi, total penerimaan agroindustri Lidah buaya setelah adanya optimasi. Satuan yang digunakan adalah rupiah (Rp).

1 = Kendala bahan baku $(\mathrm{Kg})$

$2=$ Kendala gula $(\mathrm{kg})$

$3=$ Kendala Sirup (botol)

4 = Kendala Agar-agar (bungkus)

$5=$ Kendala Air mineral (liter)

$6=$ Kendala Kemasan (cup)

7 = Kendala Tenaga kerja (JKO)

$\mathrm{X}_{1}=$ Jumlah hasil produksi nata de aloe $(\mathrm{Kg})$

$\mathrm{X}_{2} \quad$ = Jumlah hasil produksi selai lidah buaya $(\mathrm{Kg})$

$\mathrm{C}_{1} \quad=$ Penerimaan nata de aloe (Rp)

$\mathrm{C}_{2} \quad$ = Penerimaan selai lidah buaya (Rp)

$\mathrm{a}_{11}=$ Kebutuhan bahan baku untuk pembuatan nata de aloe $(\mathrm{Kg})$

$\mathrm{a}_{12}=$ Kebutuhan bahan baku untuk pembuatan selai lidah buaya $(\mathrm{Kg})$

$\mathrm{b}_{1} \quad=$ Ketersediaan bahan baku lidah buaya $(\mathrm{Kg})$

$\mathrm{a}_{21}=$ Kebutuhan Gula untuk pembuatan nata de aloe $(\mathrm{Kg})$ $\mathrm{a}_{22}=$ Kebuuhan Gula untuk pembuatan selai lidah buaya $(\mathrm{Kg})$

$\mathrm{b}_{2} \quad=$ Ketersediaan Gula (Kg)

$\mathrm{a}_{31}=$ Kebutuhan Sirup untuk pembuatan nata de aloe (botol))

$\mathrm{a}_{32}=$ Kebutuhan Sirup untuk pembuatan selai lidah buaya (botol)

$\mathrm{b}_{3} \quad=$ Ketersediaan Sirup (botol)

$\mathrm{a}_{41}=$ Kebutuhan Agar-agar untuk pembuatan nata de aloe (bungkus))

$\mathrm{a}_{42}=$ Kebutuhan Agar-agar untuk pembuatan selai lidah buaya (bungkus)

$\mathrm{b}_{4} \quad=$ Ketersediaan Agar-agar (bungkus)

$\mathrm{a}_{51}=$ Kebutuhan Air mineral untuk pembuatan nata de aloe (liter)

$\mathrm{a}_{52}=$ Kebutuhan Air mineral untuk pembuatan selai lidah buaya (liter)

$b_{5} \quad=$ Ketersediaan Air mineral (liter)

$\mathrm{a}_{61}=$ Kebutuhan Kemasan untuk pembuatan nata de aloe (cup)

$\mathrm{a}_{62}=$ Kebutuhan Kemasan untuk pembuatan selai lidah buaya (cup)

$\mathrm{b}_{6} \quad=$ Ketersediaan Kemasan (cup)

$\mathrm{a}_{71}=$ Kebutuhan Tenaga kerja untuk pembuatan nata de aloe (JKO)

$\mathrm{a}_{72}=$ Kebutuhan Tenaga kerja untuk pembuatan selai lidah buaya (JKO)

$\mathrm{b}_{7} \quad=$ Ketersediaan Tenaga kerja (JKO)

\section{HASIL DAN PEMBAHASAN}

\section{Kondisi Aktual Agroindustri Lidah Buaya}

Data yang digunakan berdasarkan produksi terakhir yang dilakukan agroindustri LIBUA pada saat penelitian, tercatat bahwa jumlah bahan baku yang dikorbankan oleh perusahaan untuk memproduksi nata de aloe dan selai adalah 100 kilogram.

\section{Penggunaan Bahan Baku Pelepah Lidah Buaya}

Penggunaan bahan baku pelepah lidah buaya untuk pembuatan nata de aloe dan selai dari 125 kilogram bahan baku yang tersedia dan yang digunakan per proses produksinya yaitu 100 kilogram dengan harga Rp. 18.500,perkilogramnya, perusahaan mengalokasikan 90 kilogram untuk pembuatan nata de aloe dan menghasilkan sebanyak 33,5 kilogram, sehingga untuk menghasilkan 1 kilogram nata de aloe dibutuhkan 2,69 kilogram pelepah lidah buaya, maka biaya bahan baku pelepah lidah buaya 
untuk menghasilkan $1 \mathrm{~kg}$ nata de aloe sebesar Rp 49.765,-. $\quad$ Pengolahan selai lidah buaya memerlukan 10 kilogram pelepah lidah buaya dan menghasilkan 7 kilogram selai lidah buaya, oleh karena itu untuk setiap 1 kilogram selai dibutuhkan pelepah lidah buaya sebanyak 1,43 kilogram dengan jumlah biaya sebesar Rp. 26.455,- .

\section{Penggunaan Gula Pasir}

Penggunaan gula pasir untuk pembuatan nata de aloe dan selai secara aktual tersedia adalah 8 kilogram dan yang digunakan per proses produksinya adalah 7,5 kilogram dengan harga Rp. 14.000,-perkilogramnya, perusahaan mengalokasikan 6 kilogram untuk pembuatan nata de aloe dan menghasilkan sebanyak 33,5 kilogram, sehingga untuk menghasilkan 1 kilogram nata de aloe dibutuhkan 0,18 kilogram gula dengan biaya sebesar $\mathrm{Rp} 2.520,-$. Pengolahan selai lidah buaya memerlukan 1,5 kilogram gula dan menghasilkan 7 kilogram selai lidah buaya, oleh karena itu untuk setiap 1 kilogram selai dibutuhkan gula sebanyak 0,21 kilogram gula dengan biaya sebesar Rp. 2.940,-.

\section{Penggunaan Sirup}

Penggunaan sirup untuk pembuatan nata de aloe dan selai secara aktual bahwa sirup yang tersedia 18 botol dan yang digunakan per proses produksi adalah 15 botol dengan harga Rp. 18.500,perbotolnya, perusahaan mengalokasikan 12 botol untuk pembuatan nata de aloe dan menghasilkan sebanyak 33,5 kilogram, sehingga untuk menghasilkan 1 kilogram nata de aloe dibutuhkan 0,36 botol sirup dengan biaya sebesar Rp.6.660,-. Pengolahan selai lidah buaya memerlukan 3 botol sirup dan menghasilkan 7 kilogram selai lidah buaya, oleh karena itu untuk setiap 1 kilogram selai dibutuhkan sirup sebanyak 0,43 botol sirup dengan biaya sebesar Rp. 7.955,- .

\section{Penggunaan Agar-agar}

Penggunaan Agar-agar untuk pembuatan nata de aloe dan selai bahwa dari 20 sachet agar-agar yang tersedia dan digunakan per proses produksi dengan harga Rp. 3.500,-persacketnya, perusahaan tidak menggunakan agar-agar untuk pembuatan nata de aloe. Pengolahan selai lidah buaya memerlukan 20 sachet agar-agar dan menghasilkan 7 kilogram selai lidah buaya, oleh karena itu untuk setiap 1 kilogram selai dibutuhkan agar-agar sebanyak 2,86 sachet agaragar dengan biaya sebesar Rp. 10.010,- .

\section{Penggunaan Air Mineral}

Penggunaan air mineral untuk pembuatan nata de aloe dan selai secara aktual menunjukkan bahwa air mineral yang tersedia 114 liter dan yang digunakan 85,5 liter per proses produksi dengan harga Rp. 1.000,perliternya, perusahaan mengalokasikan seluruhnya 85,5 liter untuk pembuatan nata de aloe dan menghasilkan sebanyak 33,5 kilogram, sehingga untuk menghasilkan 1 kilogram nata de aloe dibutuhkan 2,55 liter air mineral dengan biaya sebesar Rp.2.550,-. Pengolahan selai lidah buaya tidak menggunakan air mineral.

\section{Penggunaan Kemasan}

Penggunaan kemasan untuk pembuatan nata de aloe dan selai secara aktual menunjukkan bahwa dari 395 cup kemasan yang tersedia dan yang digunakan per proses produksi dengan harga Rp. 1.000,-percupnya, perusahaan mengalokasikan 325 cup untuk pembuatan nata de aloe dan menghasilkan sebanyak 33,5 kilogram, sehingga untuk menghasilkan 1 kilogram nata de aloe dibutuhkan 9,70 cup kemasan dengan biaya sebesar Rp.9.700,-. Pengolahan selai lidah buaya memerlukan 70 cup kemasan dan menghasilkan 7 kilogram selai lidah buaya, oleh karena itu untuk setiap 1 kilogram selai dibutuhkan kemasan sebanyak 10 cup kemasan dengan biaya sebesar Rp. 10.000,-

\section{Penggunaan Tenaga Kerja}

Penggunaan tenaga kerja untuk pembuatan nata de aloe dan selai secara aktual menunjukkan bahwa tenaga kerja yang tersedia 30 JKO dan yang digunakan 25 JKO per proses produksi dengan upah Rp. 10.000,-perJKOnya, perusahaan mengalokasikan 22,5 JKO untuk pembuatan nata de aloe dan menghasilkan sebanyak 33,5 kilogram, sehingga untuk menghasilkan 1 kilogram nata de aloe dibutuhkan 0,67 JKO tenaga kerja dengan upah perkilogramnya sebesar Rp.6.700,-. Pengolahan selai lidah buaya memerlukan 2,5 JKO tenaga kerja dan menghasilkan 7 kilogram selai lidah buaya, oleh karena itu untuk setiap 1 kilogram selai dibutuhkan tenaga kerja sebanyak 0,36 JKO dengan upah perkilogramnya sebesar Rp. 3.600,-. 


\section{Penerimaan Agroindustri Lidah Buaya Secara Aktual}

Berdasarkan analisis aktual mengenai penggunaan bahan baku pelepah lidah buaya, gula pasir, sirup, agar-agar, air mineral, kemasan dan tenaga kerja, maka dapat diperoleh total penerimaan dari kedua produk tersebut menunjukkan total produk yang dihasilkan sebesar 40,5 kilogram dengan total penerimaan Rp 3.875.000,- untuk satu kali proses produksi ( selama 3 hari). Produk nata de aloe sebesar 33,5 kilogram dengan harga Rp. 100.000,perkilogramnya, maka diperoleh penerimaan dari nata de aloe sebesar Rp. 3.350.000,-, sedangkan untuk selai dihasilkan sebesar 7 kilogram dengan harga Rp. 75.000,perkilogramnya, sehingga diperoleh penerimaan dari selai sebesar Rp. 525.000,-.

\section{Kondisi Optimal Agroindustri Lidah Buaya}

Data untuk kebutuhan bahan baku, gula pasir, sirup, agar-agar, air mineral, kemasan dan tenaga kerja sudah terkumpul, kemudian diolah dan dianalisis dengan Linear Programming.

\section{Penggunaan Bahan Baku}

Penggunaan bahan baku optimal untuk produksi nata de aloe dan selai lidah buaya adalah dengan mengalikan masing-masing hasil produksi yang telah diketahui dari perhitungan dengan penggunaan bahan baku per 1 kilogram dari masing-masing output menunjukkan dari hasil analisis Linear Programming melalui program QM Windows, perusahaan dianjurkan untuk memproduksi nata de aloe sebanyak 40,72 kilogram $(40,72 \mathrm{~kg}=40720$ gram $=393$ cup $)$ dan tidak memproduksi selai lidah buaya. Tabel 13 menunjukkan bahwa tidak ada aktifitas produksi selai lidah buaya, karena semua ketersediaan bahan baku, bahan - bahan lainnya dan tenaga kerja telah habis terserap oleh nata de aloe. Dengan harga yang ditawarkan untuk setiap 1 kilogramnya yaitu $\mathrm{Rp}$ 100.000,- memberikan penerimaan sebesar Rp. 4.072.000,-. Oleh karena itu kombinasi penggunaan ketersediaan bahan baku, bahan - bahan lainnya dan tenaga kerja di perusahaan Agroindustri Libua akan lebih optimal apabila digunakan untuk nata de aloe saja.

\section{Penggunaan Gula Pasir}

Penggunaan gula untuk produksi nata de aloe dan selai lidah buaya menunjukkan, hasil produksi nata de aloe sebanyak 40,72 kilogram, diketahui penggunaan gula pasir per 1 kilogram output dibutuhkan 0,18 kg, sehingga gula pasir yang dibutuhkan untuk menghasilkan 40,72 kilogram output adalah sebanyak 7,33 kg,

Dari penjelasan pada tabel 14 tersebut tentunya ketersediaan gula pasir hampir seluruhnya digunakan untuk memproduksi nata de aloe, karena jumlah gula pasir yang tersedia untuk pembuatan nata de aloe dan selai lidah buaya adalah sebesar $8 \mathrm{~kg}$.

\section{Penggunaan Sirup}

Penggunaan sirup untuk produksi nata de aloe dan selai lidah buaya menunjukkan, hasil produksi nata de aloe sebanyak 40,72 kilogram, penggunaan sirup per 1 kilogram output adalah 0,36 botol, sehingga sirup yang dibutuhkan untuk menghasilkan 40,72 kilogram output adalah sebanyak 14,66 botol. Tentunya ketersediaan sirup hampir seluruhnya digunakan untuk memproduksi nata de aloe, karena jumlah sirup yang tersedia untuk pembuatan nata de aloe dan selai lidah buaya adalah sebesar 18 botol.

\section{Penggunaan Agar-agar}

Penggunaan Agar-agar untuk produksi nata de aloe dan selai lidah buaya menunjukkan, hasil produksi nata de aloe sebanyak 40,72 kilogram, dimana produk tersebut tidak menggunakan agar-agar, sehingga agar-agar yang dibutuhkan untuk menghasilkan 40,72 kilogram output adalah sebanyak 0 sachet, dengan demikian ketersediaannya tidak digunakan untuk memproduksi nata de aloe.

\section{Penggunaan Air Mineral}

Penggunaan Air Mineral untuk produksi nata de aloe dan selai lidah buaya menunjukkan, hasil produksi nata de aloe sebanyak 40,72 kilogram, air mineral yang digunakan per 1 kilogram output adalah 2,55 liter, sehingga air mineral yang dibutuhkan untuk menghasilkan 40,50 kilogram output adalah 103,84 liter. Dari penjelasan tersebut tentunya ketersediaan air mineral hampir seluruhnya digunakan untuk memproduksi nata de aloe, karena jumlah air mineral yang tersedia untuk pembuatan nata de aloe dan selai lidah buaya adalah sebesar 114 liter (6 galon). 


\section{Penggunaan Kemasan}

Penggunaan Kemasan untuk produksi nata de aloe dan selai lidah menunjukkan, hasil produksi nata de aloe sebanyak 40,72 kilogram, diketahui penggunaan kemasan per 1 kilogram output dibutuhkan 9,70 cup, sehingga kemasan yang dibutuhkan untuk menghasilkan 40,50 kilogram output adalah sebanyak 395 cup. Hal ini tentunya ketersediaan kemasan seluruhnya digunakan untuk memproduksi nata de aloe, karena jumlah kemasan yang tersedia untuk pembuatan nata de aloe dan selai lidah buaya adalah sebesar 395 cup.

\section{Penggunaan Tenaga Kerja}

Penggunaan Tenaga Kerja untuk nata de aloe dan selai lidah buaya menunjukkan, hasil produksi nata de aloe sebanyak 40,72 kilogram, diketahui penggunaan tenaga kerja per 1 kilogram output dibutuhkan 0,67 JKO, sehingga tenaga kerja yang dibutuhkan untuk menghasilkan 40,72 kilogram output adalah sebanyak 27,28 JKO. Dengan demikian ketersediaan tenaga kerja hampir seluruhnya digunakan untuk memproduksi nata de aloe, karena jumlah tenaga kerja yang tersedia adalah sebesar $30 \mathrm{JKO}$.

\section{Penerimaan Agroindustri Lidah Buaya}

Hasil optimasi memberikan penerimaan kepada perusahaan sebesar Rp. 4.072.000,- dari total produksi olahan lidah buaya yaitu 40,72 kilogram dengan harga $\mathrm{Rp} 100.000,-/ \mathrm{kg}$, dengan rincian untuk output nata de aloe sebesar 40,72 kilogram dan selai tidak diproduksi.

\section{Perbedaan Penerimaan Setelah Dilakukan Optimasi}

Terdapat perbedaan besar penerimaan antara yang menggunakan solusi optimal dengan keadaan aktualnya, lebih jelasnya dapat dilihat pada Tabel berikut:

Tabel 3. Perbedaan Penerimaan Sebelum dan setelah optimis.

\begin{tabular}{|c|c|c|c|c|c|c|}
\hline \multirow{2}{*}{$\begin{array}{l}\text { Output } \\
\text { (Kg) }\end{array}$} & \multirow{2}{*}{$\begin{array}{c}\text { Harga } \\
\text { (Rp/Kg) }\end{array}$} & \multicolumn{2}{|c|}{ Sebelum Optimasi } & \multicolumn{2}{|c|}{ Setelah Optimasi } & \multirow{2}{*}{$\begin{array}{l}\text { Perbedaan } \\
\text { Penerimaan } \\
\text { (Rp) }\end{array}$} \\
\hline & & $\begin{array}{c}\text { Jumlah } \\
\text { Output } \\
\text { (Kg) }\end{array}$ & $\begin{array}{c}\text { Penerimaan } \\
\text { (Rp) }\end{array}$ & $\begin{array}{l}\text { Jumlah } \\
\text { Output } \\
\text { (Kg) }\end{array}$ & $\begin{array}{l}\text { Penerimaan } \\
\text { (Rp) }\end{array}$ & \\
\hline Nata de aloe & 100.000 & 33,50 & 3.350 .000 & 40,72 & 4.072 .000 & 722.000 \\
\hline Selai & 75.000 & 7,00 & 525.000 & 0 & 0 & $(525.000)$ \\
\hline \multicolumn{2}{|c|}{ Total } & 40,50 & 3.875 .000 & 40,72 & 4.072 .000 & 197.000 \\
\hline
\end{tabular}

Tabel tersebut menunjukkan, secara aktual jumlah produksi agroindustri lidah buaya menjadi nata de aloe dan Selai adalah sebesar 40,50 kilogram dengan rincian 33,50 kilogram nata de aloe dan 7 kilogram selai lidah buaya. Berbeda dengan hasil optimasi yang hanya memproduksi nata de aloe sebesar 40,72. Jika dilihat dari jumlah output secara aktual lebih kecil dibanding secara optimal.

Secara optimal perusahaan mampu menghasilkan penerimaan sebesar Rp. 4,072,000,- , berbeda dengan secara aktual dimana jumlah nominal yang diterima perusahaan adalah Rp. 3.875.000,-. Sehingga selisih antara aktual dengan solusi optimal sebesar Rp. 197.000,- per satu kali produksi. Dilihat dari perbedaan penerimaan tersebut yang cukup besar, namun tidak menutup kemungkinan selai lidah buaya masih tetap dapat diproduksi untuk memenuhi permintaan konsumen.

\section{KESIMPULAN}

Berdasarkan hasil penelitian dan pembahasan, maka dapat ditarik kesimpulan sebagai berikut : Kondisi aktual agroindustri berbahan baku lidah buaya pada agroindustri Libua, berdasarkan penggunaan bahan baku adalah 90 kilogram untuk nata de aloe dan 10 kilogram untuk selai. Penggunaan gula pasir adalah 6 kilogram untuk nata de aloe dan 1,5 kilogram untuk selai. Penggunaan sirup adalah 12 botol untuk nata de aloe dan 3 botol untuk selai. Penggunaan agaragar adalah hanya untuk selai yaitu 20 sacket. Penggunaan air mineral adalah 85,5 liter hanya untuk nata de aloe. Penggunaan kemasan yaitu 325 cup untuk nata de aloe dan 70 cup untuk selai. Penggunaan tenaga kerja yaitu 22,5 JKO untuk nata de aloe dan 2,5 JKO untuk selai, sehingga diperoleh total penerimaan sebesar Rp. 3.875.000,-

Kondisi optimal agroindustri berbahan baku lidah buaya pada agroindustri Libua yang hanya diproduksi nata de aloe saja, berdasarkan penggunaan bahan baku adalah 109,54 kilogram, 
Gula pasir 7,33 kilogram, sirup 14,66 botol, air mineral 103,84 liter, kemasan 395 cup dan tenaga kerja 27,28 JKO, sehingga diperoleh penerimaan sebesar Rp. 4.072.000,-

Perbedaan penerimaan setelah dilakukan optimasi adalah sebesar Rp. 197.000,- .

\section{DAFTAR PUSTAKA}

Betty Rofatin, Hendar Nuryaman dan Suyudi (2016). Optimasi Agroindustri Stroberi. Jurnal Mimbar Agribisnis ISSN 2460-4321 Volume 1 Nomer 3. Juli 2016

J. Supranto. 1983. Teknik Pengambilan Keputusan. Rineka Cipta. Jakarta.

J. Supranto. 1983. Linear programming. Fakultas Ekonomi Universitas Indonesia. Jakarta

Nana Supriyatna (2010). Optimasi Pengolahan Tepung Lidah Buaya Pontianak (Alor chinensis, Beaker) sebagai Bahan Baku Alami Handbody Lotion). Pontianak

Nasir, M. 1988. Matode Penelitian. Galia Indonesia Jakarta.

Pangestu Subagyo, Marwan Asri, Titani Handoko. 2000. Dasar-dasar Operations Research Edisi 2.Yogyakarta:BPFE
R. Hidayat (2009). Optimasi Usahatani Lidah Buaya (Aloe vera) di Pontianak

Soeharjo, A. 1990. Konsep dan Ruang Lingkup Agroindustri. Kumpulan Makalah Agribisnis. Jurusan Sosial Ekonomi Pertanian. IPB. Bogor.

Soekartawi. 1992. Linear Programming.CV Rajawali. Jakarta Utara.

Sri Mulyono. 2007. Riset Operasi.Fakultas Ekonomi Universitas Indonesia. Jakarta

Tarmizi. 2005. (http:/kuliahitukeren.blogspot.com/2013 103/pengertian-optimasi-dan-linear.html. $10 / 05 / 2013)$

Zakaria. 2000. Analisis Nilai Tambah Agroindustri Lanting di Kabupaten Kebumen Jawa Tengah. Tesis Program Pascasarjana Ekonomi Pertanian. UGM. Yogyakarta. (tidak dipublikasikan)

Zakiyah Darajat (2015). Pemanfaatan Daging Lidah Buaya (Aloe vera) untuk Pembuatan Nata de Aloe. Fakultas Tarbiyah dan Keguruan, UIN Ar-Raniry Aceh. 